\title{
Skin tattooing as an effective tool for delivering DNA and protein vaccine immunogens
}

\author{
Y Chiu ${ }^{1 *}$, X Jiang ${ }^{1}$, R Kumar ${ }^{2}$, CE Hioe ${ }^{3}$, S Zolla-Pazner ${ }^{3}$, X Kong ${ }^{1}$ \\ From AIDS Vaccine 2012 \\ Boston, MA, USA. 9-12 September 2012
}

\section{Background}

Skin is an excellent site for vaccine administration due to the abundance of antigen presenting cells and easy access. When DNA or protein is delivered into the skin, uptake and expression of immunogens can lead to a rapid and robust induction of immune responses.Skin tattooing has been suggested as a useful tool delivering vaccines intradermally. We have chosen to use the skin tattooing technique to deliver both DNA and protein immunogens that are focusing the immune response on the highly immunogenic V3 region of HIV-1 gp120.

\section{Methods}

A GFP-containing plasmid was used first to optimize the protocol for skin tattooing on BALB/c mice. Subsequently, $\mathrm{BALB} / \mathrm{c}$ mice were immunized using a DNA prime/Protein boost regimen. DNA skin tattooing was used first as the prime to deliver a gp120-encoding DNA plasmid intradermally at weeks 0,2 , and 4 . The animals were then given a fusion protein, V3-bearing cholera toxin subunit B (V3-CTB), via skin tattooing (Group1; $\mathrm{n}=5$ ) or intramuscular injection (Group2; $\mathrm{n}=5$ ) at weeks 10 and 14 . Two weeks after the final immunization, the sera were collected and analyzed.

\section{Results}

GFP expressed in skin cells was visualized by confocal microscopy showing that skin tattooing can effectively deliver DNA into these cells. ELISA assays using sera drawn after the final immunization confirmed that tattoodelivered DNA followed by V3-CTBelicited V3 binding antibodies, and these antibodies have potent neutralizing activities in an HIV pseudovirus neutralization assay.

'NYU School of Medicine, New York, NY, USA

Full list of author information is available at the end of the article

\section{Conclusion}

Immunization by skin tattooing is an easy, effective, and economical way to administer both DNA and protein vaccines. Interestingly, the needle perforations may serve as a potent and natural adjuvant for the immunization, making skin tattooing a promising vaccine delivery technique.

\section{Author details}

${ }^{1}$ NYU School of Medicine, New York, NY, USA. ${ }^{2}$ Veterans Affairs New York Harbor Healthcare System, New York, NY, USA. ${ }^{3}$ Departments of Pathology / NYU School of Medicine, New York, NY, USA.

Published: 13 September 2012

\section{doi:10.1186/1742-4690-9-S2-P338}

Cite this article as: Chiu et al: Skin tattooing as an effective tool for delivering DNA and protein vaccine immunogens. Retrovirology 20129 (Suppl 2):P338.
Submit your next manuscript to BioMed Central and take full advantage of:

- Convenient online submission

- Thorough peer review

- No space constraints or color figure charges

- Immediate publication on acceptance

- Inclusion in PubMed, CAS, Scopus and Google Scholar

- Research which is freely available for redistribution
() Biomed Central 